\title{
Identification of the Source for Salmonella Contamination of Carcasses in a Large Pig Slaughterhouse
}

\author{
Hang Zeng ${ }^{1,2}$, Geertrui Rasschaert ${ }^{1}\left(\mathbb{D}\right.$, Lieven De Zutter $^{2}\left(\mathbb{D}\right.$, Wesley Mattheus ${ }^{3}$ and Koen De Reu ${ }^{1, *}$ \\ 1 Flanders Research Institute for Agriculture, Fisheries and Food (ILVO), Brusselsesteenweg 370, \\ B-9090 Melle, Belgium; hang.zeng@ugent.be (H.Z.); Geertrui.Rasschaert@ilvo.vlaanderen.be (G.R.) \\ 2 Department of Veterinary Public Health and Food Safety, Faculty of Veterinary Medicine, Ghent University, \\ Salisburylaan 133, B-9820 Merelbeke, Belgium; Lieven.DeZutter@UGent.be \\ 3 Infectious Diseases in Humans, Bacterial Diseases, Sciensano, B-1180 Brussels, Belgium; \\ Wesley.Mattheus@sciensano.be \\ * Correspondence: Koen.dereu@ilvo.vlaanderen.be; Tel.: +32-9-272-3043
}

Citation: Zeng, H.; Rasschaert, G.;

De Zutter, L.; Mattheus, W.; De Reu,

K. Identification of the Source for

Salmonella Contamination of

Carcasses in a Large Pig

Slaughterhouse. Pathogens 2021, 10,

77. https://doi.org/10.3390/

pathogens10010077

Received: 25 December 2020

Accepted: 14 January 2021

Published: 17 January 2021

Publisher's Note: MDPI stays neutral with regard to jurisdictional clai$\mathrm{ms}$ in published maps and institutional affiliations.

Copyright: $(\odot 2021$ by the authors. Licensee MDPI, Basel, Switzerland. This article is an open access article distributed under the terms and conditions of the Creative Commons Attribution (CC BY) license (https:// creativecommons.org/licenses/by/ $4.0 /)$.

\begin{abstract}
To identify the major source of Salmonella contamination in a pig slaughterhouse, samples were collected from the clean and unclean area and Salmonella isolates were further typed. Carcasses entering the clean area showed a Salmonella contamination rate of $96.7 \%$ in the oral cavity and $55.0 \%$ in the rectum content samples. Evisceration seemed not to be critical as the contamination rate of the carcasses was similar before (16.7\%) and after (18.3\%) this slaughter step. In the unclean area, a limited number of oral cavity samples were positive after bleeding, while a dramatic increase of positives was observed after dehairing. Salmonella was detected in up to $0.01 \mathrm{~mL}$ of the recycled water collected from the dehairing machine. Genotyping of Salmonella isolates showed that similar pulsotypes were present in the oral cavity and recycled water. Based on these observations it can be concluded that the recycled water used in the dehairing machine was the major source for the carcass contamination in this slaughterhouse.
\end{abstract}

Keywords: Salmonella; pig carcasses; slaughterhouse; dehairing; evisceration

\section{Introduction}

In the EU in 2018, salmonellosis was the second most commonly reported zoonotic disease in humans and was the most important cause of food-borne outbreaks. Moreover, pork was recognized as an important source of human salmonellosis cases [1].

Salmonella contamination may occur during any stage of pork production in which the slaughterhouse plays an important role [2-4]. At the time of slaughter, the presence of Salmonella in pigs is dependent on the colonization of the animals at farm level and the contamination that can occur during the transport and lairage period [5]. Pesciaroli et al., after investigating the association between the Salmonella numbers in pig intestines and the presence on carcasses, suggested that the reduction of Salmonella numbers in the intestines of slaughtered pigs would result in fewer contaminated carcasses [6]. In another study, a quantitative exposure assessment was carried out by building a modular risk model covering the pork production chain from farm to fork [7]. Those authors concluded that internal infection status and the external contamination of a pig is associated and could thus potentially contaminate the pork carcasses.

Along the pig slaughter line, several factors have been associated with Salmonella contamination on carcasses. Swabs of the oral cavity of carcasses after bleeding revealed a $14 \%$ Salmonella positivity rate [8], with these positive tests being significantly correlated with the carcass contamination during slaughter. Biasino et al. [9] also demonstrated that the oral cavity, tonsils and tongue of the pig play an important role in the contamination of the pig carcass. Scalding decreases Salmonella contamination on the exterior of the carcass but depends on a sufficiently high temperature of the scalding water $\left(62{ }^{\circ} \mathrm{C}\right)[10,11]$. In the 
next step of the slaughter process, fecal material may be spread onto the carcass surface during dehairing and may result in a rise in the level of carcass contamination $[12,13]$. In the clean area, the intestines and pluck set (e.g., heart, liver, lungs, tongue, etc.) are removed from the pig carcass during evisceration, which is another step where pig carcasses can become contaminated with Salmonella; this step is also associated in which crosscontamination [14-20]. Apart from the factors discussed above, steps such as polishing and carcass splitting are also critical for Salmonella contamination [21,22].

The process hygiene criterium set by European Commission Regulation 217/2014 stipulated that no more than three out of 50 sampled carcasses by swab may be contaminated with Salmonella [23]. If more are detected, the slaughterhouse is required to take corrective actions. According to the report of European Food Safety Authority and European Centre for Disease Prevention and Control (EFSA and ECDC), in 2018 the proportion of Salmonella-positive carcasses before chilling based on official controls was $2.7 \%$ in the EU [1]. Salmonella Typhimurium and S. Derby accounted for $27.3 \%$ and $61.8 \%$ of all isolates, respectively, collected from the positive carcasses [1]. Both $S$. Typhimurium and $S$. Derby were among the top five Salmonella serovars that caused human salmonellosis cases in the EU.

Control of Salmonella in pig slaughterhouses requires the identification of critical points or steps where (cross-)contamination can occur, together with modifications of the slaughter procedures/techniques to reduce the risk of contamination. Both the critical steps and the intervention plans can differ among slaughterhouses [11,24].

The aim of this study was to identify the main source of Salmonella contamination in a large Belgian pig slaughterhouse with a history of carcass contamination above the EU process hygiene criterium for pig carcasses. To confirm our findings, the identified source of contamination was also monitored in other slaughterhouses.

\section{Results}

\subsection{Samples from the Clean Area}

The first samples collected (first sampling event in the clean area-S1) were from 30 carcasses originating from seven farms. The most contaminated site of those carcasses was the oral cavity, with $93.3 \%(28 / 30)$ samples testing positive for Salmonella, whereas $53.3 \%(16 / 30)$ samples of the rectal content tested positive (Table 1$)$. For the carcass swabs of breast and elbow combined, $16.7 \%$ (5/30) were positive before evisceration and $6.7 \%$ $(2 / 30)$ after evisceration. Before evisceration, three breast and three elbow swabs were Salmonella positive, with one carcass contaminated at both sites. Salmonella Derby was the only serotype that was found in this batch of samples. In total 34 isolates were typed by Pulsed-Field Gel Electrophoresis (PFGE) and the Salmonella Derby isolates belonged to pulsotype $\mathrm{F}(76.5 \%, 26 / 34)$ and $\mathrm{I}^{\ddagger}(23.5 \%, 8 / 34)$.

Table 1. Presence, serotypes and pulsotypes of Salmonella in samples from the clean area.

\begin{tabular}{|c|c|c|c|c|c|c|c|c|c|c|c|c|}
\hline \multirow{3}{*}{$\begin{array}{c}\text { Sampling Point } \\
\text { Sample type }\end{array}$} & \multirow{2}{*}{\multicolumn{2}{|c|}{$\begin{array}{c}\text { Before Evisceration } \\
\text { Oral cavity } \\
\end{array}$}} & \multirow{2}{*}{\multicolumn{2}{|c|}{$\begin{array}{c}\text { At Evisceration } \\
\text { Rectal content }\end{array}$}} & \multicolumn{4}{|c|}{ Before Evisceration } & \multicolumn{4}{|c|}{ After Evisceration } \\
\hline & & & & & \multicolumn{2}{|r|}{ Breast } & \multicolumn{2}{|r|}{ Elbow } & \multicolumn{2}{|r|}{ Breast } & \multicolumn{2}{|c|}{ Elbow } \\
\hline & No. * & $\mathrm{S}(\%)-\mathrm{P} * *$ & No. & $\mathrm{S}(\%)-\mathrm{P}$ & No. & $\mathrm{S}(\%)-\mathrm{P}$ & No. & $\mathrm{S}(\%)-\mathrm{P}$ & No. & $\mathrm{S}(\%)-\mathrm{P}$ & No. & $\mathrm{S}(\%)-\mathrm{P}$ \\
\hline $\begin{array}{c}\text { Sampling event } \\
1(\mathrm{~S} 1)^{+}\end{array}$ & 28 & $\begin{array}{c}\text { Derby } \\
(100)-F / I^{\ddagger, \&}\end{array}$ & 16 & $\begin{array}{c}\text { Derby } \\
(100)-\mathrm{F} / \mathrm{I} \ddagger\end{array}$ & 3 & $\begin{array}{c}\text { Derby } \\
(100) — \mathrm{~F} / \mathrm{I}^{\ddagger}\end{array}$ & 3 & $\begin{array}{c}\text { Derby } \\
(100)-\mathrm{F} / \mathrm{I}^{\ddagger}\end{array}$ & 2 & $\begin{array}{l}\text { Derby } \\
(100)-\mathrm{F} / \mathrm{I} \ddagger\end{array}$ & 0 & \\
\hline $\begin{array}{c}\text { Sampling event } \\
2 \text { (S2) }\end{array}$ & 30 & $\begin{array}{c}\text { Brand }^{\#} \\
(16.7)-\mathrm{K} \\
\text { Derby (83.3)- } \\
\mathrm{B} / \mathrm{C} / \mathrm{D} / \mathrm{I}\end{array}$ & 17 & $\begin{array}{c}\text { Brand } \\
(5.9)-K \\
\text { Derby } \\
(94.1)-B / I\end{array}$ & 1 & $\begin{array}{l}\text { Derby } \\
(100)-C\end{array}$ & 4 & $\begin{array}{l}\text { Derby } \\
(100)- \\
B / C / I\end{array}$ & 7 & $\begin{array}{c}\text { Derby (14.3) } \\
-\mathrm{C} \\
\text { Typh } \\
\text { (85.7)-T/W }\end{array}$ & 8 & $\begin{array}{c}\text { Derby } \\
\text { (75)-C/I } \\
\text { Typh } \\
(25)-\mathrm{T}\end{array}$ \\
\hline
\end{tabular}

${ }^{\dagger}$ sampling event number; ${ }^{*}$ Positive sample number, each time 30 samples were collected; ${ }^{* *}$ Serotype (\%: percentage of each serotype out of total positive samples) —: pulsotype; \#: Brand: Brandenburg; Typh: Typhimurium. \&: The symbol $¥$ after the letter means that one extra band was presented in that fingerprint.

The second batch of samples (repeat after 6 weeks-S2) came from 30 carcasses originating from five farms. Salmonella was detected in the oral cavity of all of these carcasses (30/30) and in 56.7\% (17/30) of the rectal content. Before evisceration 16.7\% (5/30) 
of the carcasses were contaminated with Salmonella while 30\% (9/30) of the carcasses were detected as positive after evisceration. After evisceration, six carcasses were contaminated with Salmonella on both sampled sites (breast and elbow). The 50 characterized Salmonella isolates were identified as S. Derby pulsotypes B (20.0\%, 10/50), C (30.0\%, 15/50), D (2.0\%, $1 / 50)$ and I (22.0\%, 11/50), S. Brandenburg (pulsotype K, 10.0\%, 5/50) and S. Typhimurium (pulsotypes T: 14\%, 7/50 and W: $2.0 \%, 1 / 50$ ). Salmonella Derby was the dominant serotype (74.0\%), which was found in all sample types. Salmonella Brandenburg (pulsotype K) was isolated only from the oral cavity and rectal content. Salmonella Derby was the only serotype found in the carcass swabs before evisceration; it was typed as pulsotypes B, C and I. After evisceration, $S$. Derby pulsotypes $C$ and I and $S$. Typhimurium pulsotype $T$ and $W$ were isolated from the carcasses. In addition, three carcasses were contaminated with both $S$. Typhimurium pulsotype T and $S$. Derby (two pulsotype I and one pulsotype C) after evisceration.

\subsection{Sampling in the Unclean Area}

The third batch of samples (the first sampling event in the unclean area-S3) were from 30 carcasses originating from five farms. After bleeding 16.7\% (5/30) of the carcasses were Salmonella positive, while after dehairing all carcasses $(100 \%)$ were contaminated with Salmonella (Table 2). More specifically, after bleeding, three swabs from the oral cavity and three swabs from the rectum were Salmonella positive, with one carcass testing Salmonella positive for both the oral cavity and the rectum. After dehairing, 28 swabs from the oral cavity and 29 swabs from the rectum were Salmonella positive, and from 27 carcasses, Salmonella was isolated from both sites. Within this batch of samples, Salmonella Derby pulsotype $C(8.3 \%, 3 / 36)$ and $S$. Typhimurium pulsotypes $\mathrm{O}^{\ddagger}(5.6 \%, 2 / 36), \mathrm{Z}(2.8 \%, 1 / 36)$ were identified after bleeding. After dehairing, $S$. Derby pulsotypes $C(66.7 \%, 24 / 36)$ and I $(11.1 \%, 4 / 36)$ and $S$. Infantis pulsotype $M(2.8 \%, 1 / 36)$ and $S$. Typhimurium pulsotype U $(2.8 \%, 1 / 36)$ were identified.

Table 2. Presence, serotypes and pulsotypes of Salmonella in samples from the unclean area.

\begin{tabular}{|c|c|c|c|c|c|c|c|c|c|c|}
\hline \multirow{3}{*}{$\begin{array}{c}\text { Sampling Point } \\
\text { Sample type }\end{array}$} & \multicolumn{4}{|c|}{ After Bleeding } & \multirow{2}{*}{\multicolumn{2}{|c|}{$\begin{array}{c}\begin{array}{c}\text { Before } \\
\text { Dehairing }\end{array} \\
\text { Oral cavity }\end{array}$}} & \multicolumn{4}{|c|}{ After Dehairing } \\
\hline & \multicolumn{2}{|c|}{ Oral cavity } & \multicolumn{2}{|r|}{ Rectal content } & & & \multicolumn{2}{|r|}{ Oral cavity } & \multicolumn{2}{|r|}{ Rectum } \\
\hline & No. * & $\mathrm{S}(\%)-\mathrm{P}^{* *}$ & No. & $\mathrm{S}(\%)-\mathrm{P}$ & No. & $\mathrm{S}(\%)-\mathrm{P}$ & No. & $\mathrm{S}(\%)-\mathrm{P}$ & No. & $\mathrm{S}(\%)-\mathrm{P}$ \\
\hline $\begin{array}{l}\text { Sampling event } 1 \\
\text { (S3) }^{+}\end{array}$ & 3 & $\begin{array}{c}\text { Derby }(66.7)-\mathrm{C} \\
\text { Typh }^{\#}(33.3)-\mathrm{O} \\
\neq, \&\end{array}$ & 3 & $\begin{array}{c}\text { Derby (13.3)-C } \\
\text { Typh (66.7)-O } \mathrm{O}^{\ddagger} / \mathrm{Z}\end{array}$ & NS & & 28 & Derby $(100) — C / I$ & 29 & $\begin{array}{c}\text { Derby (93.1)-C/I } \\
\text { Infantis (3.4)-M } \\
\text { Typh (3.4)-U }\end{array}$ \\
\hline$\underset{\text { (S4) }}{\text { Sampling event } 2}$ & NS & & NS & & 1 & $\begin{array}{c}\text { Typh } \\
(100)-\mathrm{T} 4\end{array}$ & 28 & $\begin{array}{c}\text { Derby (17.9)-C/D/F } \\
\text { Panama (3.6)-J } \\
\text { Rissen (28.6)-H } \\
\text { Typh (50)-O/W /X/Y }\end{array}$ & NS & \\
\hline
\end{tabular}

${ }^{\dagger}$ sampling event number; NS: Not sampled; * Positive sample number, each time 30 samples were collected; ** Serotype (\%: percentage of each serotype out of total positive samples) —: pulsotype; ${ }^{\#}$ Typh: Typhimurium; ${ }^{*}$ : The symbol ${ }^{\ddagger}$ after the letter means that one extra band was presented in that fingerprint.

In the water of the scalding tank at the beginning and the end of the sampling event, no Salmonella was detected (Table 3 ). The water temperature of the scalding tank ranged between $59.2^{\circ} \mathrm{C}$ and $60.3^{\circ} \mathrm{C}$. The temperature of the water at the outlet of the three parts of the dehairing machine ranged from $28.4{ }^{\circ} \mathrm{C}$ to $38.2{ }^{\circ} \mathrm{C}$. At the start of the sampling event, the water of the dehairing machine was positive for $S$. Derby (pulsotypes C: $26.3 \%, 5 / 19$, I: $15.8 \%, 3 / 19$ ) in up to $0.1 \mathrm{~mL}$ water from parts 1 and 3 , and $1 \mathrm{~mL}$ from part 2 . Approximately $1.5 \mathrm{~h}$ later, after sampling was completed, water samples were more contaminated with Salmonella, detected in $0.01 \mathrm{~mL}$ from parts 1 and 3, and in $0.1 \mathrm{~mL}$ from part 2. In addition to $S$. Derby pulsotypes C $(26.3 \%, 5 / 19)$ and I (15.8\%, 3/19), S. Typhimurium pulsotype $R(5.3 \%, 1 / 19)$ and $W^{\ddagger}(5.3 \%, 1 / 19)$ and $S$. Infantis pulsotype $M(5.3 \%, 1 / 19)$ were also identified in those water samples. 
Table 3. Presence, serotypes and pulsotypes of Salmonella in water samples from the scalding tank and the dehairing machine (from the unclean area).

\begin{tabular}{|c|c|c|c|c|c|c|c|c|}
\hline \multirow{2}{*}{\multicolumn{4}{|c|}{ Water Samples }} & \multirow{2}{*}{ Temp in ${ }^{\circ} \mathrm{C}$} & \multicolumn{4}{|c|}{ Sample Analysis/mL } \\
\hline & & & & & 10 & 1 & 0.1 & 0.01 \\
\hline \multirow{4}{*}{$\begin{array}{l}\text { Scalding } \\
\text { tank }\end{array}$} & \multirow{4}{*}{ Sampling event $1(\mathrm{~S} 3)^{\dagger}$} & \multirow{2}{*}{ start } & SP & 60.3 & $\mathrm{~N}$ & $\mathrm{~N}$ & $\mathrm{~N}$ & NA \\
\hline & & & $\mathrm{EP}$ & 60.2 & $\mathrm{~N}$ & $\mathrm{~N}$ & $\mathrm{~N}$ & NA \\
\hline & & \multirow{2}{*}{ end } & $\mathrm{SP}$ & 59.7 & $\mathrm{~N}$ & $\mathrm{~N}$ & $\mathrm{~N}$ & NA \\
\hline & & & $\mathrm{EP}$ & 59.2 & $\mathrm{~N}$ & $\mathrm{~N}$ & $\mathrm{~N}$ & NA \\
\hline \multirow{12}{*}{$\begin{array}{l}\text { Dehairing } \\
\text { machine }\end{array}$} & \multirow{6}{*}{ Sampling event 1 (S3) } & \multirow{2}{*}{ part 1} & $\mathrm{SP}$ & 38.2 & Derby-C ${ }^{*}$ & Derby-C & Derby-C & $\mathrm{N}$ \\
\hline & & & $\mathrm{EP}$ & 35.0 & Derby-I & Derby-C & Derby-C & Derby-I \\
\hline & & \multirow{2}{*}{ part 2} & SP & 28.4 & Derby-I & Derby-I & $\mathrm{N}$ & $\mathrm{N}$ \\
\hline & & & $\mathrm{EP}$ & 35.5 & Derby-C & Infantis-M & Derby-I & $\mathrm{N}$ \\
\hline & & \multirow{2}{*}{ part 3} & $\mathrm{SP}$ & 34.8 & Derby-C & Derby-C & Derby-I & $\mathrm{N}$ \\
\hline & & & $\mathrm{EP}$ & 37.5 & Derby-C & Derby-C & Typh-R & Typh-W \\
\hline & \multirow{6}{*}{ Sampling event 2 (S4) } & \multirow{2}{*}{ part 1} & $\mathrm{SP}$ & 36.2 & Derby-C & Typh \#_O & $\mathrm{N}$ & $\mathrm{N}$ \\
\hline & & & $\mathrm{EP}$ & 36.1 & Derby-B & Typh-Q & $\mathrm{N}$ & $\mathrm{N}$ \\
\hline & & \multirow{2}{*}{ part 2} & SP & 32.2 & Panama-J & $\mathrm{N}$ & $\mathrm{N}$ & $\mathrm{N}$ \\
\hline & & & $\mathrm{EP}$ & 32.1 & Panama-J & Typh-Q & $\mathrm{N}$ & $\mathrm{N}$ \\
\hline & & \multirow[t]{2}{*}{ part 3} & SP & 37.3 & $\begin{array}{l}\text { Derby-C } \\
\text { Panama-J }\end{array}$ & Typh-O & $\mathrm{N}$ & $\mathrm{N}$ \\
\hline & & & $\mathrm{EP}$ & 37.9 & Derby-C & Derby-B & $\mathrm{N}$ & $\mathrm{N}$ \\
\hline
\end{tabular}

${ }^{\dagger}$ sampling event number; SP: at the start of the sampling event; EP: at the end of the sampling event; NA: Not analyzed; N: Salmonella was not detected; Temp: temperature; ${ }^{*}$ Serotype-Pulsotype; ${ }^{*}$ Typh: Typhimurium.

The fourth time samples were taken (repeat after 10 days-S4), and 30 sampled carcasses originated from two farms. S. Typhimurium pulsotype $Q(5.0 \%, 1 / 20)$ was detected in 1 out of 30 (3.3\%) oral cavity swabs before dehairing while after dehairing, $93.3 \%(28 / 30)$ oral cavity swabs were Salmonella positive. Salmonella Derby pulsotype B $(10.0 \%, 2 / 20), C(5.0 \%, 1 / 20), F(5.0 \%, 1 / 20)$, S. Panama pulsotype J $(5.0 \%, 1 / 20)$, S. Rissen pulsotype $\mathrm{H}(30 \%, 6 / 20)$ and $S$. Typhimurium O $(5.0 \%, 1 / 20), \mathrm{W}^{\ddagger}(25.0 \%, 5 / 20), \mathrm{X}(5.0 \%$, $1 / 20)$ and $Y(5.0 \%, 1 / 20)$ were identified from these samples. The temperature of the water at the outlet of the three parts of the dehairing machine ranged from $32.1^{\circ} \mathrm{C}$ to $37.9^{\circ} \mathrm{C}$. Collected water samples were positive in up to $1 \mathrm{~mL}$ both at the beginning and the end of sampling event. In water collected at the beginning of the sampling event, $S$. Derby pulsotype C $(16.7 \%, 2 / 12)$, S. Panama pulsotype J $(16.7 \%, 2 / 12)$ and $S$. Typhimurium O $(16.7 \%, 2 / 12)$ were detected. At the end of the sampling event, $S$. Derby pulsotypes B $(16.7 \%, 2 / 12), C(8.3 \%, 1 / 12), S$. Panama pulsotype J $(8.3 \%, 1 / 12)$ and $S$. Typhimurium pulsotype $Q(16.7 \%, 2 / 12)$ were isolated from the water samples.

\subsection{Salmonella in the Water at the Outlet of the Dehairing Machine during Slaughter}

The results of the first batch of water samples (S5) are shown in Table 4. Even before commencement of that day's slaughter activities, S. Derby, S. London, S. Panama, and $S$. Typhimurium were detected in water sampled at the outlet of the dehairing machine (sample taken at 6:35 AM). Salmonella was detected in volumes of 1-10 mL. After two hours of slaughter activities, $S$. Derby pulsotype F was detected from all three parts of the dehairing machine and in higher concentrations (concentrations of $0.1-0.01 \mathrm{~mL}$ tested positive). After four hours of slaughter activities, the same $S$. Derby pulsotypes was found in all water samples of $0.01 \mathrm{~mL}$. Temperature of sampled water ranged between $26.3^{\circ} \mathrm{C}$ and $39.0^{\circ} \mathrm{C}$ (Table 4$)$. 
Table 4. Presence, serotypes and pulsotypes of Salmonella in water samples from the dehairing machine during the slaughter activities (first sampling event ${ }^{+}-\mathrm{S} 5^{+}$).

\begin{tabular}{|c|c|c|c|c|}
\hline \multicolumn{2}{|c|}{ Sampled Time } & 6: 35 a.m. & 9:00 a.m. & 11:00 a.m. \\
\hline \multirow{3}{*}{$\begin{array}{l}\text { Dehairing machine } \\
\text { part } 1\end{array}$} & Temperature $/{ }^{\circ} \mathrm{C}$ & $26.3^{\circ} \mathrm{C}$ & $39.0^{\circ} \mathrm{C}$ & $30.4^{\circ} \mathrm{C}$ \\
\hline & smallest positive volume & $10 \mathrm{~mL}$ & $0.1 \mathrm{~mL}$ & $0.01 \mathrm{~mL}$ \\
\hline & serotype-pulsotype & Panama-J & Derby-F & Derby-F \\
\hline \multirow{3}{*}{$\begin{array}{l}\text { Dehairing machine } \\
\text { part } 2\end{array}$} & Temperature $/{ }^{\circ} \mathrm{C}$ & $32.2^{\circ} \mathrm{C}$ & $35.8^{\circ} \mathrm{C}$ & $30.0^{\circ} \mathrm{C}$ \\
\hline & smallest positive volume & $1 \mathrm{~mL}$ & $0.1 \mathrm{~mL}$ & $0.01 \mathrm{~mL}$ \\
\hline & serotype-pulsotype & $\begin{array}{c}\text { Panama-A } \\
\text { Typh }{ }^{\#-V}\end{array}$ & Derby-F & Derby-F \\
\hline \multirow{3}{*}{$\begin{array}{l}\text { Dehairing machine } \\
\text { part } 3\end{array}$} & Temperature $/{ }^{\circ} \mathrm{C}$ & $36.4^{\circ} \mathrm{C}$ & $33.6^{\circ} \mathrm{C}$ & $20.4^{\circ} \mathrm{C}$ \\
\hline & smallest positive volume & $1 \mathrm{~mL}$ & $0.01 \mathrm{~mL}$ & $0.01 \mathrm{~mL}$ \\
\hline & serotype-pulsotype & $\begin{array}{c}\text { Derby-a } \\
\text { London-L }\end{array}$ & Derby-F & Derby-F \\
\hline
\end{tabular}

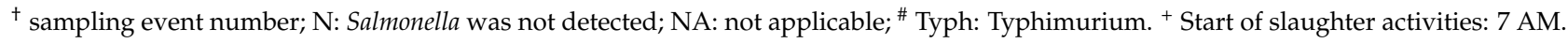

The results of the second batch of water samples (S6) are listed in Table 5. No Salmonella was found in the water before slaughter commenced that day. After one hour of slaughter, $S$. Derby pulsotypes $\mathrm{C}, \mathrm{I}, \mathrm{N}$ and $S$. Typhimurium $\mathrm{O}^{\ddagger}$ and $\mathrm{S}$ were detected in the water of all three parts of the machine in volumes of $0.1-1 \mathrm{~mL}$. After four hours of processing, $S$. Derby pulsotype I, S. London pulsotype L and $S$. Typhimurium pulsotype V were detected in comparable volumes of water sampled.

Table 5. Occurrence, serotypes and pulsotypes of Salmonella in water samples from the dehairing machine during the slaughter activities (second sampling event ${ }^{+}-\mathrm{S} 6^{+}$).

\begin{tabular}{|c|c|c|c|c|}
\hline \multicolumn{2}{|c|}{ Sampled Time } & 5:00 a.m. & 8:00 a.m. & 11:00 a.m. \\
\hline \multirow{2}{*}{ Dehairing machine part 1} & $\begin{array}{c}\text { Temperature } /{ }^{\circ} \mathrm{C} \\
\text { smallest positive volume }\end{array}$ & $\begin{array}{l}23.2^{\circ} \mathrm{C} \\
(\mathrm{N})\end{array}$ & $\begin{array}{c}36.0^{\circ} \mathrm{C} \\
1 \mathrm{~mL}\end{array}$ & $\begin{array}{l}39.5^{\circ} \mathrm{C} \\
0.1 \mathrm{~mL}\end{array}$ \\
\hline & serotype-pulsotype & NA & Derby $-\mathrm{C} / \mathrm{N}$ & $\begin{array}{l}\text { Derby-I } \\
\text { London-L } \\
\text { Typh }{ }^{\#-V}\end{array}$ \\
\hline \multirow{2}{*}{ Dehairing machine part 2} & $\begin{array}{c}\text { Temperature } /{ }^{\circ} \mathrm{C} \\
\text { smallest positive volume }\end{array}$ & $\begin{array}{l}29.2^{\circ} \mathrm{C} \\
(\mathrm{N})\end{array}$ & $\begin{array}{c}35.8{ }^{\circ} \mathrm{C} \\
1 \mathrm{~mL}\end{array}$ & $\begin{array}{c}34.7{ }^{\circ} \mathrm{C} \\
1 \mathrm{~mL}\end{array}$ \\
\hline & serotype-pulsotype & NA & $\begin{array}{l}\text { Derby-C } \\
\text { Typh-O } \neq \&\end{array}$ & London-L \\
\hline \multirow{2}{*}{ Dehairing machine part 3} & $\begin{array}{c}\text { Temperature } /{ }^{\circ} \mathrm{C} \\
\text { smallest positive volume }\end{array}$ & $\begin{array}{l}32.5^{\circ} \mathrm{C} \\
(\mathrm{N})\end{array}$ & $\begin{array}{l}39.3^{\circ} \mathrm{C} \\
0.1 \mathrm{~mL}\end{array}$ & $\begin{array}{l}35.8^{\circ} \mathrm{C} \\
1 \mathrm{~mL}\end{array}$ \\
\hline & serotype-pulsotype & NA & $\begin{array}{c}\text { Derby-C/I } \\
\text { Typh }-S\end{array}$ & Derby-I \\
\hline
\end{tabular}

\footnotetext{
${ }^{\dagger}$ sampling event number; N: Salmonella was not detected; NA: not applicable; ${ }^{+}$Start of slaughter activities: 7 AM; ${ }^{\#}$ Typh: Typhimurium;
}

\&: The symbol ${ }^{\ddagger}$ after the letter means that one extra band was presented in that fingerprint.

\subsection{Water Samples from Dehairing at Other Pig Slaughterhouses}

In slaughterhouse A, Salmonella was not detected in the dehairing water samples before the start of the slaughter activities, but after one hour of activity $S$. Typhimurium was detected in volumes of $1 \mathrm{~mL}$ and after $2 \mathrm{~h}$ in $10 \mathrm{~mL}$ (Table 6). Slaughterhouse B was also Salmonella negative before starting slaughtering. During slaughter, $S$. Typhimurium was detected only once (after 30 min of slaughter activity) in one of both compartments of the dehairing machine. In slaughterhouse $\mathrm{C}$, before the start of the slaughter activities the water was already contaminated in a $0.1 \mathrm{~mL}$ volume and continued to be contaminated with $S$. Typhimurium and other Salmonella serovars. 
Table 6. Occurrence of Salmonella in water samples from the dehairing machine during the slaughter activities in three other slaughterhouses A, B and C.

\begin{tabular}{|c|c|c|c|c|c|c|}
\hline \multicolumn{2}{|c|}{ Slaughterhouse } & Sampling Time & Before Slaughter & After $0.5 \mathrm{~h}$ & After $1 \mathrm{~h}$ & After $2 \mathrm{~h}$ \\
\hline \multirow{3}{*}{ A } & \multirow{3}{*}{$\begin{array}{l}\text { Dehairing } \\
\text { machine }\end{array}$} & lowest positive volume & $(\mathrm{N})$ & $(\mathrm{N})$ & $1 \mathrm{~mL}$ & $10 \mathrm{~mL}$ \\
\hline & & PCR results & NA & NA & Typh. & Typh. \\
\hline & & & & After $1 \mathrm{~h}$ & After $2 \mathrm{~h}$ & After 3-4 h \\
\hline \multirow{4}{*}{ B } & \multirow{2}{*}{ Part 1} & lowest positive volume & $(\mathrm{N})$ & $1 \mathrm{~mL}$ & $(\mathrm{~N})$ & $(\mathrm{N})$ \\
\hline & & PCR results & NA & Typh. & NÁ & NA \\
\hline & \multirow{2}{*}{ Part 2} & lowest positive volume & $(\mathrm{N})$ & $(\mathrm{N})$ & $(\mathrm{N})$ & $(\mathrm{N})$ \\
\hline & & PCR results & NA & NA & NÁ & NÁ \\
\hline \multirow{2}{*}{$\mathrm{C}$} & Dehairing & smallest positive volume & $0.1 \mathrm{~mL}$ & $0.1 \mathrm{~mL}$ & $0.1 \mathrm{~mL}$ & $0.1 \mathrm{~mL}$ \\
\hline & machine & PCR results & Typh \#/S. spp. & Typh & Typh & Typh/S. spp. \\
\hline
\end{tabular}

N: Salmonella was not detected; NA: not applicable; " Typh: Typhimurium.

\section{Discussion}

In a pig slaughterhouse with a history of Salmonella positive carcasses, during six sampling events consecutive samples were taken to detect the origin of the Salmonella contamination of the carcasses. Different studies have already revealed several critical points that may cause Salmonella contamination of pig carcasses during slaughter, e.g., scalding and dehairing [13], evisceration [14,16], etc.

The present study identified an important source of Salmonella contamination of pig carcasses during slaughter. Results of two batches of samples taken six weeks apart in the clean area during evisceration did not confirm our first hypothesis that the evisceration step could be responsible for the historical contamination. The high contamination of the oral cavity (97\%) and rectal content (55\%) samples with Salmonella entering the clean area indicated high numbers of positive carcasses coming from the unclean area. Other studies reported Salmonella contamination rates for the oral cavity of $14.0 \%$ after bleeding [8] and $54.3 \%$ before evisceration [17], while the contamination rate for the rectal content at evisceration was $13.3 \%$ [8] and $30.9 \%$ [17], for the colon content $18.8 \%$ [25] and for the cecal content 33.8\% [16], 31.4\% [26] and 36.5\% [27]. Moreover, carcasses were found to be Salmonella positive at the entrance to the clean area. Characterization of the Salmonella isolates showed that in most cases the same serotypes and genotypes were present in the oral cavity and the rectal content and on carcasses within the same day. These data indicated that the source of contamination had to be found either in lairage and/or in the unclean area of the slaughterhouse.

The results of the samples first taken in the unclean area revealed a dramatic increase in the Salmonella contamination rate of the oral cavity and rectal content during the scalding/dehairing step. Salmonella was not detected in the water from the scalding tank, thus this process step could not be considered as a source for the contamination of these two sites. Indeed, water in the scalding tank at $60^{\circ} \mathrm{C}$ even may reduce the Salmonella contamination of pig carcasses [11]. A second batch of samples confirmed that the contamination of the oral cavity and rectal content occurred during the dehairing step. All water samples collected at the outlets of dehairing machine were Salmonella positive and contained up to at least 100 cells $/ \mathrm{mL}$. Characterization of isolates showed that serologically and genetically similar Salmonella strains were present in the water from the dehairing machine, in the oral cavity and in the rectum. These data indicated that the recycled water was the initial source of the contamination of the carcasses. Indeed, the mouth and the anus of dead pigs both relax, allowing the water used during the dehairing process to possibly enter both cavities. When the used water is contaminated and enters the oral and rectal cavity, it could contaminate both sites. When carcasses are hung up after the dehairing process, contaminated fluid from the oral and rectal cavities could leak out, leading to contamination of carcasses during subsequent steps such as polishing and evisceration. 
Water samples collected before the start of slaughter activities proved that the water was Salmonella positive even before the day's activities began. This indicates that the slaughterhouse's standard cleaning and disinfection protocol (first batch of fresh water samples) was not able to eliminate the pathogen, whereas in the second batch of fresh water samples (after cleaning and disinfection performed by the aid of a specialized company) Salmonella was not detected. The number of Salmonella $/ \mathrm{mL}$ recycled water also showed an increasing trend during slaughter. The water used in the dehairing machine was recycled during the entire slaughter day. According to the slaughterhouse, the recycled water was injected into the machine at $50{ }^{\circ} \mathrm{C}$. When it exited the machine during slaughter activities, the water temperature varied between $30^{\circ} \mathrm{C}$ and $40^{\circ} \mathrm{C}$. The recycled water, supplemented with potable water when needed, was stored in a buffer tank. The recycled water was pumped from this tank and heated before use. The water temperature when the water left the dehairing machine and when it was stored in the buffer tank allows the growth of Salmonella, and the water temperature after heating was not high enough to eliminate Salmonella. These temperatures allowed the Salmonella cells to survive in the recycled water and may have even encouraged them to multiply [28].

As a comparison, the possible impact of the dehairing step on Salmonella contamination in other slaughterhouses was evaluated by analyzing the water from the dehairing machine before slaughter activities began and again during slaughter. In two slaughterhouses (A and C) using recycled water Salmonella was found in the water at different times during production and in one of them (slaughterhouse C) Salmonella was even detected before the daily slaughter began. Slaughterhouse B used fresh potable water heated up to more than $50^{\circ} \mathrm{C}$; Salmonella was detected only once in the used water. This water could possibly become positive on occasion when a Salmonella positive carcass passes through. In almost all slaughterhouses in Belgium, recycled water is used on a daily basis in the dehairing machine. In practice in those slaughterhouses daily fresh water is added to a buffer tank before starting the production and further used and recycled during the day, if needed, supplemented with extra potable water during the day. This practice of recycling water after heating to a suitable temperature (over $50{ }^{\circ} \mathrm{C}$ ) is authorised by the competent authorities in Belgium. Few slaughterhouses, as is the case for slaughterhouse B, uses constantly fresh potable water as this results in a lot of water consumption and high costs.

Based on this study, we believe that the sampling strategy, sample types and number of sampled animals per sampling event can also be useful in comparable case studies to detect possible main causes of Salmonella contaminations in pig slaughterhouses.

\section{Materials and Methods}

\subsection{Pig Slaughterhouse}

This study was conducted in a Belgian pig slaughterhouse with a slaughter capacity of approximately 550 pigs per hour. Slaughterhouses in Belgium with this slaughter speed are considered as big slaughterhouses. The slaughterhouse had sometimes failed to meet the process hygiene criterium for Salmonella on pig carcasses during recent years [23].

The overview of the slaughter process is shown schematically in Figure 1 . In the unclean area, the pigs were stunned with $\mathrm{CO}_{2}$ in groups of eight to ten pigs. Then the pigs were hung on the slaughter line and bled manually. After bleeding, the pigs were scalded in a water bath for $7 \mathrm{~min}$ at $60^{\circ} \mathrm{C}$. Next, the hairs from the pig carcasses were removed in a dehairing machine consisting of three connected compartments with a separate water outlet at the bottom of each compartment. This water was recycled during the slaughter day. After singeing and polishing, the carcasses were transferred to the clean area for evisceration. The abdomen was opened, and the white and red organs were removed manually, after which the carcasses were split into two parts. After meat inspection, carcass dressing and classification, the carcasses were moved to the chilling room. The live weight of the slaughtered pigs varied between 90 and $110 \mathrm{~kg}$. 


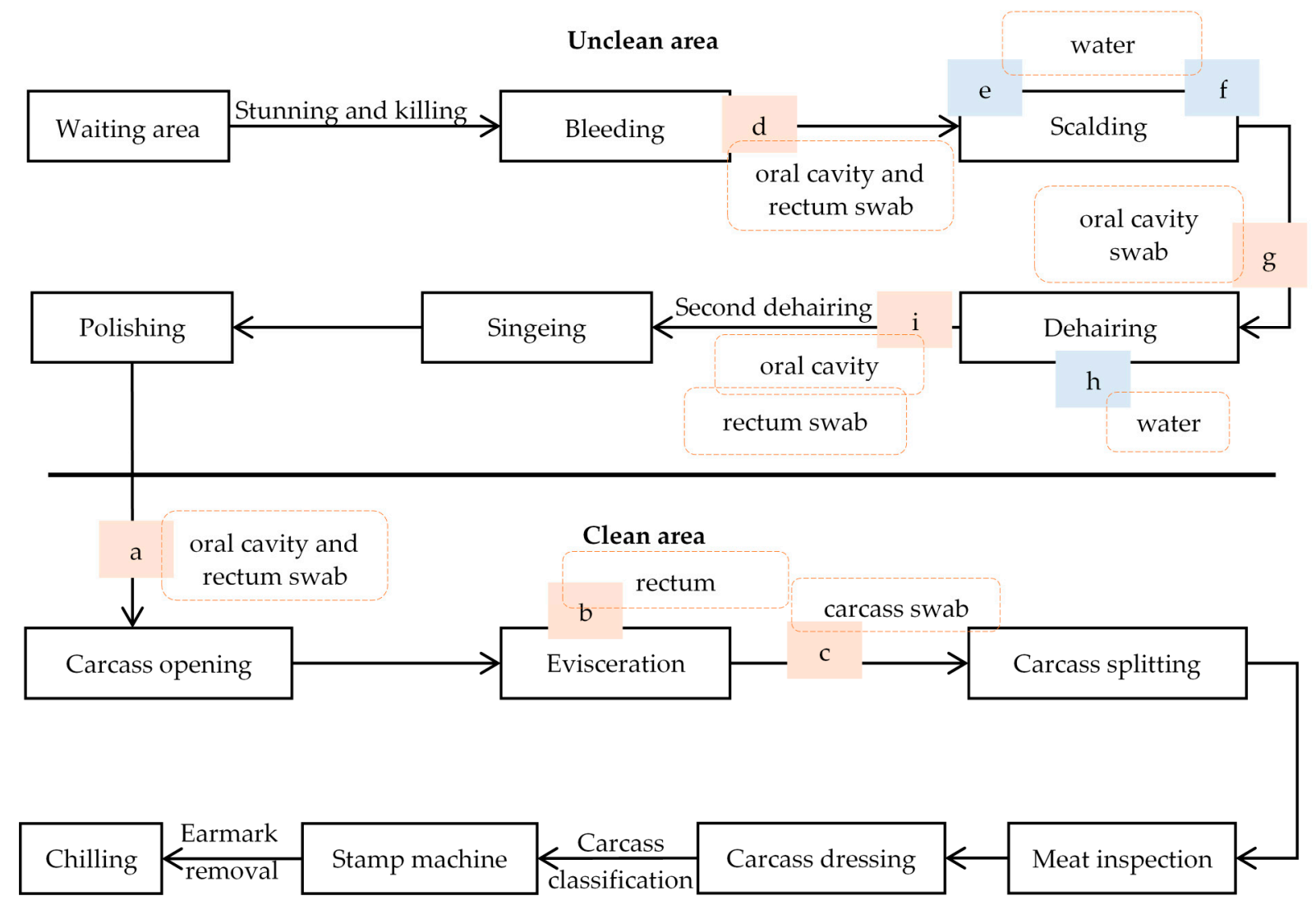

Figure 1. Schematic overview of the slaughter process in the pig slaughterhouse. a-i: sampling points during the different sampling events. Blue boxes refer to water samples, orange boxes refer to samples taken from the carcasses.

\subsection{Sampling Design}

\subsubsection{Overview of Sampling Events}

The timeline of the six sampling events (S1 to S6) in the slaughterhouse is given in Figure 2. To identify the main contamination source, four sampling events took place: twice in the clean area, and then twice in the unclean area. Each time, 30 slaughtered pigs were sampled at random with an interval of two minutes between carcasses. The collection of samples began 3-4 $\mathrm{h}$ after the start of the day's slaughter in each case. The origin of each of the 30 carcasses of the pigs was noted. No information on the Salmonella status of the batches to which the sampled pigs belonged, was available. In addition, in a later stage, water samples were taken twice from the dehairing machine. Moreover, water samples were taken once in three other slaughterhouses A, B, C (A, B and C are codes of other different slaughterhouses) and before and during the slaughter activity.

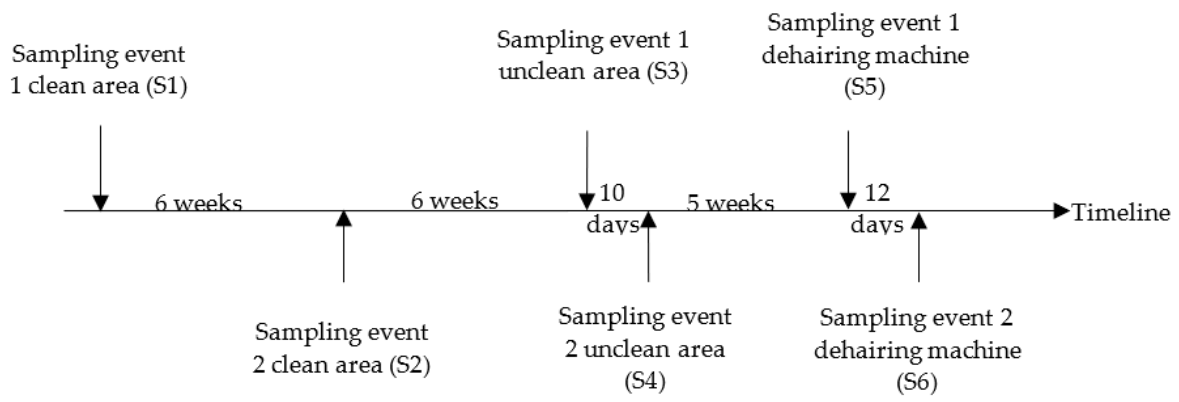

Figure 2. Overview of the sampling event in the pig slaughterhouse. 


\subsubsection{Sampling in the Clean Area}

Our first hypothesis was that the carcasses had mostly become contaminated with Salmonella during evisceration. Therefore, samples were taken from the oral cavity when the carcasses entered the clean area, i.e., before evisceration (Figure 1: a). Besides, the carcass sites breast $\left(200 \mathrm{~cm}^{2}\right)$ and elbow $\left(200 \mathrm{~cm}^{2}\right)$ were sampled before (Figure 1: a) and after evisceration (Figure 1: c) on the same carcass. Before and after evisceration, the left side and the right side of the carcass were swabbed, respectively. Samples were taken with sponge swabs (Sponge-Stick, 3M $\mathrm{M}^{\mathrm{TM}}$, Diegem, Belgium) premoistened with $10 \mathrm{~mL}$ of maximum recovery diluent (MRD) (Oxoid, Basingstoke, UK). Further, whole intestinal packages of the sampled carcasses were collected after removal of the white organs (Figure 1: b). The rectum was tied and excised for analysis. The same sampling protocol was used during both sampling events (S1 and S2).

\subsubsection{Sampling in the Unclean Area}

We revised our hypothesis based on the combined results of both sampling events from the clean area, as this did not indicate a clear source of contamination. We then hypothesized that the Salmonella contamination took place during scalding/dehairing process. To test this, samples from 30 carcasses were collected in the unclean area during a sampling event (S3). The oral cavity of each carcass was sampled with a sponge swab premoistened with $10 \mathrm{~mL}$ MRD after bleeding (Figure 1: d) and dehairing (Figure 1: i). After bleeding and dehairing, also the rectum of the same carcasses was sampled with a cotton swab (a $4 \mathrm{~cm}$ diameter ball made of medical cotton handled with a sterile metal forceps) premoistened with MRD. In addition, water samples $(100 \mathrm{~mL})$ were collected at the beginning and end of the sampling event from the entrance and the exit of the scalding tank (Figure 1: e-f) and from the water outlet of the three compartments of the dehairing machine (Figure 1: h). At water sampling, the water temperature was also measured. Temperature of the scalding tank was measured directly, while an extra water sample from the dehairing machine was collected for immediate temperature measurement.

Based on these results, a second sampling event (S4) from the unclean area was carried out, to confirm that the contamination indeed occurred in the dehairing machine. Oral cavity swabs were taken just before (Figure 1: g) and after the dehairing (Figure 1: i) step from 30 carcasses. At the same time, water samples were also collected from the dehairing machine as described above.

\subsubsection{Salmonella in the Water at the Outlet of the Dehairing Machine during Slaughter}

During two following sampling events (S5 and S6), water samples were taken during slaughter to track Salmonella contamination of the recycled water used in the dehairing machine. First samples (S5) were taken after the slaughterhouse cleaned and disinfected the water recycling system and the dehairing machine, and later samples (S6) were taken again after a specialized company had cleaned and disinfected the recycling system and the dehairing machine. Water samples were taken from the water outlet of the three compartments. These samples were collected before slaughter began (at $7 \mathrm{AM}$ ) and after 1-2 and $4 \mathrm{~h}$ of slaughter activities. The before-slaughter samples were taken after the dehairing machine had been running for $15 \mathrm{~min}$.

\subsubsection{Samples from Other Pig Slaughterhouses}

In order to check if the identified source for Salmonella contamination was also present in other slaughterhouses, a similar protocol was used to collect water samples from the dehairing machine in three other pig slaughterhouses (A, B, C). Slaughterhouses A and $\mathrm{C}$ had a dehairing machine with a single compartment, while slaughterhouse $\mathrm{B}$ had a dehairing machine with two compartments. Slaughterhouses $A$ and $C$ recycled the water during the slaughter day, whereas slaughterhouse B used fresh potable water. Each slaughterhouse was visited once. The water outlet samples of the dehairing machine (two parts of the apparatus in slaughterhouse B) were collected 10 min before the start 
of the slaughter activities in the three slaughterhouses and after $0.5,1$ and $2 \mathrm{~h}$ during the slaughter process in slaughterhouse A; after 1, 2 and $3 \mathrm{~h}$ during the slaughter process in slaughterhouse B; and after 1, 2 and $3.5 \mathrm{~h}$ during the slaughter process in slaughterhouse $\mathrm{C}$. The temperature of the water inside the dehairing machine was obtained from each slaughterhouse; this was $40-50{ }^{\circ} \mathrm{C}$, over $50{ }^{\circ} \mathrm{C}$ and $25-30{ }^{\circ} \mathrm{C}$ in slaughterhouses $\mathrm{A}, \mathrm{B}$ and $\mathrm{C}$, respectively.

\subsection{Salmonella Isolation}

After transporting the samples to the laboratory under cooled conditions, analyses were started the same day (1.5-2 h after the sampling).

Twenty-five grams of rectal content were collected aseptically from the tied rectum and mixed with $225 \mathrm{~mL}$ Buffered Peptone Water (BPW) (Oxoid, Basingstoke, UK). To each sponge swab sample, $90 \mathrm{~mL}$ BPW was added, while $40 \mathrm{~mL}$ BPW was added to each cotton swab from the rectum. Afterwards, the samples were homogenized for $1 \mathrm{~min}$ in a Stomacher blender. For the water samples, $10 \mathrm{~mL}$ and $1 \mathrm{~mL}$ of the water samples were mixed with $90 \mathrm{~mL}$ and $9 \mathrm{~mL} \mathrm{BPW}$, respectively. Further, $1 \mathrm{~mL}$ of the $10^{-1}$ and $10^{-2}$ (only for water from the dehairing machine) dilutions of the water samples were mixed with $9 \mathrm{~mL}$ BPW.

The isolation method was based on ISO 6597-1 (ISO, 2017). Briefly, after 16-20 h of pre-enrichment in BPW at $37 \pm 1^{\circ} \mathrm{C}, 0.1 \mathrm{~mL}$ of the enriched broth was transferred in three spots on Modified Semi-Solid Rappaport-Vassiliadis (MSRV) (Oxoid) plates. These MSRV plates were incubated at $41.5 \pm 0.5^{\circ} \mathrm{C}$ for 24 and $48 \mathrm{~h}$. After $24 \mathrm{~h}$ of incubation, a loopful of the migration area was transferred from each suspected plate to Xylose Lysine Deoxycholate Agar (XLD) (Oxoid) plates and incubated at $37 \pm 1{ }^{\circ} \mathrm{C}$ for further detection and isolation. A further incubation until $48 \mathrm{~h}$ was applied for the negative MSRV plates and the same procedure was followed. From each XLD plate, one to two suspect colonies were purified and stored at $-80{ }^{\circ} \mathrm{C}$ for further confirmation and typing.

The collected Salmonella isolates were confirmed at the genus level by polymerase chain reaction (PCR) using the primers described by Aabo et al. [29]. To identify isolates belonging to $S$. Typhimurium serotype, the primers described by Lin et al. [30] were used.

\subsection{Characterization of the Salmonella Isolates}

First, the repetitive element palindromic-polymerase chain reaction (rep-PCR) was applied to limit the number of non-Typhimurium Salmonella isolates to be serotyped [31]. From each rep-PCR cluster, at least one isolate was serotyped by the Belgian Salmonella reference laboratory using the Kauffman-White scheme (Sciensano, Brussels, Belgium).

Second, Pulsed-Field Gel Electrophoresis (PFGE) was applied according to the protocol of PulseNet [32]. Depending on the rep-PCR results, one up to five isolates per sample type and per cluster were selected randomly for PFGE with $50 \mathrm{U}$ of XbaI enzyme (New England Biolab, Hitchin, UK). One $S$. Typhimurium isolate per sample type was also selected randomly for PFGE. The electrophoresis was applied by a Chef Mapper (Bio-Rad, Hercules, CA, USA). The obtained pulsotypes were analyzed with BioNumerics software V.7.6 (Applied Maths, Sint-Martens-Latem, Belgium) using the Pearson correlation with $2 \%$ optimization. Further, the pulsotypes were assigned to clusters and each cluster was given an alphabet letter (uppercase ' $A$ ' and lowercase ' $a$ ' indicate different pulsotypes). The symbol $\ddagger$ after the letter means that one extra band was presented in that isolate compared to the dominant pulsotype within the serotype.

The Salmonella isolates from the water samples collected in the slaughterhouses A, B and $C$ were confirmed by PCR but were not further characterized.

\section{Conclusions}

The aim of this study was to find the main source of the Salmonella contamination in a slaughterhouse with a history of Salmonella positive carcasses. Based on the results, the recycled water used in the dehairing machine was identified as an important source 
for Salmonella contamination. In two other slaughterhouses that also use recycled water in the dehairing machine, water also tested positive for Salmonella at different times during production. These data indicated that slaughterhouses using recycled water in the dehairing machine may be at higher risk for contamination of carcasses with Salmonella. In order to reduce this risk, slaughterhouses should look for applicable methods to eliminate Salmonella from the recycled water before injecting it into the dehairing machine. Obtained results also indicate that sufficient attention must be given to cleaning and disinfection of the dehairing machine and the water recycling circuit after slaughter.

Author Contributions: Conceptualization, G.R., K.D.R. and L.D.Z.; methodology, G.R., K.D.R. and L.D.Z.; formal analysis, H.Z. and G.R.; investigation, H.Z., G.R., K.D.R., L.D.Z. and W.M.; writing-original draft preparation, H.Z.; writing-review and editing, H.Z., G.R., K.D.R. and L.D.Z.; supervision, G.R., K.D.R. and L.D.Z.; project administration, G.R., K.D.R. and L.D.Z.; funding acquisition, G.R., K.D.R. and L.D.Z. All authors have read and agreed to the published version of the manuscript.

Funding: This research was funded by Flemish Agency of Innovation and Entrepreneurship (VLAIO), grant number HBC.2016.0061, and Hang Zeng was funded by China Scholarship Council, grant number 201706910091.

Institutional Review Board Statement: Not applicable.

Informed Consent Statement: Not applicable.

Data Availability Statement: Data sharing not applicable.

Acknowledgments: The authors would like to thank the Flemish Agency of Innovation and Entrepreneurship (VLAIO), Flanders' Food and the participating companies and sectors for their financial support of the Flanders' Food SAFEMEAT project. We also gratefully acknowledge the team members of the QAML and the molecular lab at ILVO, the participating slaughterhouses and the members of the user group of the SAFEMEAT project for their constructive input. We also acknowledge Liselotte De Ridder from CID Lines (Ieper, Belgium) for the drafting the cleaning and disinfection protocol of the dehairing machine and for her practical help, and Miriam Levenson for English-language editing. Hang Zeng received funding from China Scholarship Council (No. 201706910091).

Conflicts of Interest: The authors declare no conflict of interest.

\section{References}

1. EFSA and ECDC. The European Union One Health 2018 Zoonoses Report. EFSA J. 2019, 17. [CrossRef]

2. Arguello, H.; Carvajal, A.; Naharro, G.; Arcos, M.; Rodicio, M.R.; Martin, M.C.; Rubio, P. Sero- and genotyping of Salmonella in slaughter pigs, from farm to cutting plant, with a focus on the slaughter process. Int. J. Food Microbiol. 2013, 161, 44-52. [CrossRef] [PubMed]

3. Prendergast, D.M.; Duggan, S.J.; Gonzales-Barron, U.; Fanning, S.; Butler, F.; Cormican, M.; Duffy, G. Prevalence, numbers and characteristics of Salmonella spp. on Irish retail pork. Int. J. Food Microbiol. 2009, 131, 233-239. [CrossRef] [PubMed]

4. Delhalle, L.; Saegerman, C.; Farnir, F.; Korsak, N.; Maes, D.; Messens, W.; De Sadeleer, L.; De Zutter, L.; Daube, G. Salmonella surveillance and control at post-harvest in the Belgian pork meat chain. Food Microbiol. 2009, 26, 265-271. [CrossRef] [PubMed]

5. Rostagno, M.H.; Callaway, T.R. Pre-harvest risk factors for Salmonella enterica in pork production. Food Res. Int. 2012, 45, 634-640. [CrossRef]

6. Pesciaroli, M.; Cucco, L.; De Luca, S.; Massacci, F.R.; Maresca, C.; Medici, L.; Paniccià, M.; Scoccia, E.; Staffolani, M.; Pezzotti, G.; et al. Association between pigs with high caecal Salmonella loads and carcass contamination. Int. J. Food Microbiol. 2017, 242, 82-86. [CrossRef]

7. Messens, W.; Bollaerts, K.E.; Delhalle, L.; Aerts, M.; Van Der Stede, Y.; Dewulf, J.; Quoilin, S.; Maes, D.; Mintiens, K.; Grijspeerdt, $\mathrm{K}$. Development of a quantitative microbial risk assessment for human salmonellosis through household consumption of fresh minced pork meat in Belgium. Risk Anal. 2009, 29, 820-840. [CrossRef]

8. De Busser, E.V.; Maes, D.; Houf, K.; Dewulf, J.; Imberechts, H.; Bertrand, S.; De Zutter, L. Detection and characterization of Salmonella in lairage, on pig carcasses and intestines in five slaughterhouses. Int. J. Food Microbiol. 2011, 145, 279-286. [CrossRef]

9. Biasino, W.; De Zutter, L.; Woollard, J.; Mattheus, W.; Bertrand, S.; Uyttendaele, M.; Van Damme, I. Reduced contamination of pig carcasses using an alternative pluck set removal procedure during slaughter. Meat Sci. 2018, 145, 23-30. [CrossRef]

10. Chau, P.Y.; Shortridge, K.F.; Huang, C.T. Salmonella in pig carcasses for human consumption in Hong Kong: A study on the mode of contamination. J. Hyg. 1977, 78, 253-260. [CrossRef] 
11. Hald, T.; Wingstrand, A.; Swanenburg, M.; von Altrock, A.; Thornberg, B.M. The occurrence and epidemiology of Salmonella in European pig slaughterhouses. Epidemiol. Infect. 2003, 131, 1187-1203. [CrossRef] [PubMed]

12. Swart, A.N.; Evers, E.G.; Simons, R.L.L.; Swanenburg, M. Modeling of Salmonella Contamination in the Pig Slaughterhouse. Risk Anal. 2016, 36, 498-515. [CrossRef] [PubMed]

13. Borch, E.; Nesbakken, T.; Christensen, H. Hazard identification in swine slaughter with respect to foodborne bacteria. Int. J. Food Microbiol. 1996, 30, 9-25. [CrossRef]

14. Berends, B.R.; Van Knapen, F.; Snijders, J.M.A.; Mossel, D.A.A. Identification and quantification of risk factors regarding Salmonella spp. on pork carcasses. Int. J. Food Microbiol. 1997, 36, 199-206. [CrossRef]

15. Alban, L.; Stärk, K.D.C. Where should the effort be put to reduce the Salmonella prevalence in the slaughtered swine carcass effectively? Prev. Vet. Med. 2005, 68, 63-79. [CrossRef] [PubMed]

16. Arguello, H.; Carvajal, A.; Collazos, J.A.; García-Feliz, C.; Rubio, P. Prevalence and serovars of Salmonella enterica on pig carcasses, slaughtered pigs and the environment of four Spanish slaughterhouses. Food Res. Int. 2012, 45, 905-912. [CrossRef]

17. Van Damme, I.; Mattheus, W.; Bertrand, S.; De Zutter, L. Quantification of hygiene indicators and Salmonella in the tonsils, oral cavity and rectal content samples of pigs during slaughter. Food Microbiol. 2018, 71, 120-128. [CrossRef]

18. Delhalle, L.; De Sadeleer, L.; Bollaerts, K.; Farnir, F.; Saegerman, C.; Korsak, N.; Dewulf, J.; De Zutter, L.; Daube, G. Risk factors for Salmonella and hygiene indicators in the 10 largest Belgian pig slaughterhouses. J. Food Prot. 2008, 71, 1320-1329. [CrossRef]

19. Buncic, S.; Sofos, J. Interventions to control Salmonella contamination during poultry, cattle and pig slaughter. Food Res. Int. 2012, 45, 641-655. [CrossRef]

20. Vieira-Pinto, M.; Tenreiro, R.; Martins, C. Unveiling contamination sources and dissemination routes of Salmonella sp. in pigs at a Portuguese slaughterhouse through macrorestriction profiling by pulsed-field gel electrophoresis. Int. J. Food Microbiol. 2006, 110, 77-84. [CrossRef]

21. Pearce, R.A.; Bolton, D.J.; Sheridan, J.J.; McDowell, D.A.; Blair, I.S.; Harrington, D. Studies to determine the critical control points in pork slaughter hazard analysis and critical control point systems. Int. J. Food Microbiol. 2004, 90, 331-339. [CrossRef]

22. De Busser, E.V.; De Zutter, L.; Dewulf, J.; Houf, K.; Maes, D. Salmonella control in live pigs and at slaughter. Vet. J. 2013, 196, 20-27. [CrossRef] [PubMed]

23. The European Commission. European Commission Commission Regulation (EU) No 217/2014 of 7 March 2014 amending Regulation (EC) No 2073/2005 as regards Salmonella in pig carcases. Off. J. Eur. Communitites 2014, 9, 93-94.

24. Biasino, W.; De Zutter, L.; Mattheus, W.; Bertrand, S.; Uyttendaele, M.; Van Damme, I. Correlation between slaughter practices and the distribution of Salmonella and hygiene indicator bacteria on pig carcasses during slaughter. Food Microbiol. 2018, 70, 192-199. [CrossRef] [PubMed]

25. Botteldoorn, N.; Heyndrickx, M.; Rijpens, N.; Grijspeerdt, K.; Herman, L. Salmonella on pig carcasses: Positive pigs and cross contamination in the slaughterhouse. J. Appl. Microbiol. 2003, 95, 891-903. [CrossRef]

26. McDowell, S.W.J.; Porter, R.; Madden, R.; Cooper, B.; Neill, S.D. Salmonella in slaughter pigs in Northern Ireland: Prevalence and use of statistical modelling to investigate sample and abattoir effects. Int. J. Food Microbiol. 2007, 118, 116-125. [CrossRef]

27. Zhou, Z.; Li, J.; Zheng, H.; Jin, X.; Shen, Y.; Lei, T.; Sun, X.; Pan, Z.; Jiao, X. Diversity of Salmonella isolates and their distribution in a pig slaughterhouse in Huaian, China. Food Control 2017, 78, 238-246. [CrossRef]

28. International Commission on Microbiological Specifications for Foods (ICMSF). Microorganisms in Foods 5-Characteristics of Microbial Pathogens; Blackie Academic \& Professional: London, UK, 1996.

29. Aabo, S.; Rasmussen, O.F.; Roseen, L.; Sørensen, P.D.; Olsen, J.E. Salmonella identification by the polymerase chain reaction. Mol. Cell. Probes 1993, 7, 171-178. [CrossRef]

30. Lin, J.S.; Tsen, H.Y. Development and use of polymerase chain reaction for the specific detection of Salmonella typhimurium in stool and food samples. J. Food Prot. 1999, 62, 1103-1110. [CrossRef]

31. Rasschaert, G.; Houf, K.; Imberechts, H.; Grijspeerdt, K.; De Zutter, L.; Heyndrickx, M. Comparison of five repetitive-sequencebased PCR typing methods for molecular discrimination of Salmonella enterica isolates. J. Clin. Microbiol. 2005, 43, 3615-3623. [CrossRef]

32. CDC PulseNet. Standard Operating Procedure for PulseNet PFGE of Escherichia coli O157: H7, Escherichia coli non-O157 (STEC), Salmonella serotypes, Shigella sonnei and Shigella flexneri. Cent. Dis. Control Prev. Atlanta 2017, 157, 1-16. [CrossRef] 